\title{
GAMBARAN KADAR ASAM URAT PADA MAHASISWA DIPLOMA III KEPERAWATAN STIKES DIRGAHAYU SAMARINDA TAHUN 2020
}

\author{
Norsanah \\ Program Studi Diploma III Keperawatan STIKES Dirgahayu Samarinda \\ J1.Pasundan No.21 Telp.Fax.(0541) 748335 Kelurahan Jawa Kotamadya Samarinda \\ Kode Pos 75122 Kalimantan Timur \\ Email: norsanahm@gmail.com
}

\begin{abstract}
Asam urat dikenal oleh masyarakat awam atau dikenal sebagai gout arthritis yang diakibatkan oleh penimbunan Kristal monosodium di dalam tubuh. Asam urat merupakan hasil metabolisme akhir dari makanan yang mengandung zat purin, zat purin merupakan komponen asam nukleat yang terdapat dalam inti sel tubuh. Meningkatnya kadar asam urat di dalam tubuh dapat menimbulkan gangguan rasa nyeri di daerah persendian yang amat sangat nyeri bagi penderitaya. Penelitian ini bertujuan untuk mengetahui deskripsi serta menjelaskan gambaran kadar asam urat pada Mahasiswa Diploma III Keperawatan Sekolah Tinggi Ilmu Kesehatan Dirgahayu Samarinda Tahun Akademik 2020/2021. Penelitian gambaran kadar asam urat pada Mahasiswa Diploma III Keperawatan Sekolah Tinggi Ilmu Kesehatan Dirgahayu Samarinda Tahun Akademik 2020/2021 dilaksanakan selama 6 bulan (yaitu dari September 2020 sampai dengan Februari 2021) di Kampus Sekolah Tinggi Ilmu Kesehatan Dirgahayu Samarinda. Sampel penelitian gambaran kadar asam urat pada Mahasiswa Diploma III Keperawatan Sekolah Tinggi Ilmu Kesehatan Dirgahayu Samarinda Tahun Akademik 2020/2021 adalah 71 mahasiswa sampel total satu angkatan. Gambaran Kadar Asam Urat pada Mahasiswa Diploma III Keperawatan Sekolah Tinggi Ilmu Kesehatan Dirgahayu Samarinda Tahun Akademik 2020/2021. Menunjukkan bahwa ada sebanyak 14 orang $(31,0 \%)$ responden yang memiliki kadar asam urat di atas rentang normal (rentang normal asam urat laki-laki remaja 3,4-7,0 $\mathrm{mg} / \mathrm{dl}$, perempuan remaja 2,4-5,7 $\mathrm{mg} / \mathrm{dl}$ ), yaitu dari 71 orang total responden. Maka Gambaran Asam urat Pada mahasiswa Diploma III Keperawatan Sekolah Dirgahayu Samarinda tahun 2020/2021 mengalami peningkatan $31.0 \%$ dari seluruh responden.
\end{abstract}

Key Words - Usia, Jenis kelamin, Kadar Asam Urat.

\section{PENDAHULUAN}

Asam urat dikenal oleh masyarakat awam atau dikenal sebagai gout arthritis yang diakibatkan oleh penimbunan Kristal monosodium di dalam tubuh. Asam urat merupakan hasil metabplisme akhir dari makanan yang mengandung zat purin, zat purin merupakan komponen asam nukleat yang terdapat dalam inti sel tubuh. Meningkatnya kadar asam urat di dalam tubuh dapat menimbulkan gangguan rasa nyeri di daerah persendian yang amat sangat nyeri bagi penderitaya. Menumpuknya Kristal di daerah persendian, mengakibatkan tingginya kadar asam urat dalam darah. Mengkonsumsi bahan pangan yang tinggi kandungan zat purin dapat meningkatkan kadar asam urat dalam darah. Mengkonsumsi makanan yang tinggi lemak seperti makanan gorengan, makanan bersantan, margarine, 
mentega, buah-buahan seperti durian, alpukat juga berpengaruh terhadap meningkatnya kadar asam urat(Krisnatuti, 2007).

Di dalam Riset Kesehatan Dasar tahun 2012 diketahui bahwa prevalensi hiperurisemia di Indonesia ditemukan $11,9 \%$, di Jawa Timur 26,4\% (Kemenkes RI, 2013) Perbedaan kadar asam urat menurut usia dan jenis kelamin. Sebelum pubertas pada pria dan wanita berkisar 3,5 mg/dL. Setelah pubertas kadar asam urat pria meningkat secara bertahap dan dapat mencapai $5,2 \mathrm{mg} / \mathrm{dL}$, dan pada wanita biasanya tetap rendah karena memiliki hormone estrogen yang dapat mengeluarkan asam urat dalam tubuh. Kadar asam urat pada wanita mulai menunjukkan peningkatan pada masa post menopause dan dapat mencapai 4,7 $\mathrm{mg} / \mathrm{dL}$. Dikatakan kadar asam urat normal pada pria dewasa $3,4-7,0$ $\mathrm{mg} / \mathrm{dL}$ dan pada wanita dewasa 2,4 $5,7 \mathrm{mg} / \mathrm{dL}$ Asam Urat yang beredar dalam darah tidak akan menimbulkan rasa sakit jika kadarnya berada pada batas normal (Herliana,2103)

Menurut data dari Central for Disease Control and Prevention (CDC), dalam satu dekade terakhir sebanyak kira-kira 12,7 juta (17\%) anak dan remaja mengalami obesitas. Pada tahun 2011-2012, sebanyak 20,25\% anak berusia antara 12 sampai 19 tahun mengalami obesitas dan jika dibandingkan dengan kelompok usia yang lain merupakan yang paling tinggi. Dalam survei yang diselenggarakan oleh Riskesdas pada tahun 2010 dan 2013 di Indonesia, prevalensi untuk remaja usia 16-18 tahun yang gemuk naik dari $1,4 \%$ menjadi 7,3\% (Jurnal e-Biomedik (eBm), Volume 6, Nomor 1, JanuariJuni 2018)

Tujuan penelitian adalah: (1) Penelitian ini bertujuan untuk mengetahui gambaran kadar asam urat pada mahasiswa Diploma III keperawatan STIKES Dirgahayu Samarinda tahun 2020.(2) Melanjutkan penelelitian dengan Menganalisis faktor-faktor yang memperngaruhi peningkatan kadar asam urat pada mahasiswa Diploma III Keperawatan STIKES Dirgahayu 2021.

Peneleitian lanjut Pengaruh Senam Aerobik terhadap penurunan kadar asam urat pada mahasiswa tahun 2022

\section{METODE}

Penelitian ini merupakan penelitian deskriptif dengan rancangan persentase (\%),Gambaran Kadar Asam Urat Pada Mahasiswa Diploma III Keperawatan Stikes Dirgahayu Samarinda Tahun 2020. Data yang ada diperoleh melalui pengisian formulir data,informat Consent untuk pemeriksaan kadar asam urat pada responden dengan waktu bergilirian setiap hari dengan beberapa responden d Kampus Stikes Dirgahayu Samarinda antara pukul 12.00 sampai pukul 16.00 di luar jam kuliah.Pengumpulan data dilakukan mulai bulan September 2020 sampai dengan bulan Februari 2021.Pemeriksaan Kadar Asam Urat menggunakan alat Autocheck asam urat, Daftar Mahasiwa Diploma III keperawatan Semester Semester III Aktif. Hasil pemeriksaan asam urat dilakukan pada mahasiswa dilanjutkan dengan: Coding Data yang terkumpul diberi kode dalam bentuk angka, untuk mempermudah memasukkan data ke dalam tabel dan bila terdapat kesalahan pengisian dan dengan mudah dapat dilihat kesalahan yang ada karena telah diberikan kode yang ada. Tabulating Untuk mempermudah analisa dan pengolahan data serta pengambilan kesimpulan data yang dimasukkan dalam bentuk distribusi frekuensi.

Analisa data dilakukan secara deskriptif dengan melihat persentase (\%) data yang terkumpul dan disajikan dalam bentuk tabel frekuensi, analisa data ini dilanjutkan dengan membahas hasil 
penelitian dengan teori dan kepustakaan yang ada.Berdasarkan sumber data primer menunjukkan bahwa gambaran mahasiswa masuk menjadi mahasiswa tahun akademik tahun 2018/2019 adalah 2 (dua) mahasiswa atau 2,85\% dan masuk tahun tahun akademik 2019/2020 sebanyak 69 mahasiswa atau 97,15\%, Jenis kelamin laki-laki sebanyak 13 $(18,97 \%)$, perempuan sebanyak 58 $(81,03 \%)$ dari seluruh responden berjumlah 71 orang

\section{HASIL}

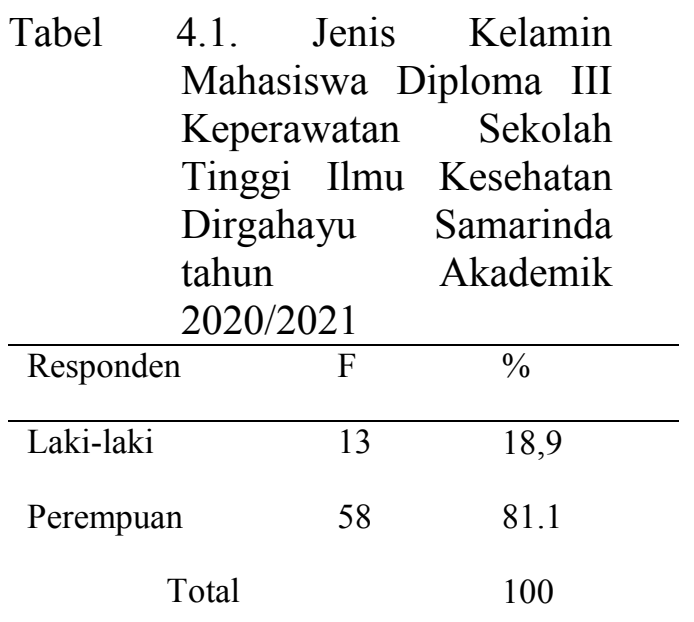

Sumber: Data primer diolah, 2021

Berdasarkan tabel 4.1 Jenis Kelamin, Responden tergambar bahwa laki laki berjumlah 13 orang $(18.9 \%)$ dan responden perempuan berjumlah 58 orang $(81.1 \%)$.

Tabel 4.2. Usia Mahasiswa Diploma III Keperawatan Sekolah Tinggi Ilmu Kesehatan Dirgahayu Samarinda tahun Akademik 2020/2021

\begin{tabular}{lllll}
\hline $\begin{array}{l}\text { Respon } \\
\text { den }\end{array}$ & $\begin{array}{l}\text { Laki- } \\
\text { laki }\end{array}$ & $\begin{array}{l}\text { pere } \\
\text { mpua } \\
\text { n }\end{array}$ & F & $\%$ \\
\hline $19-22$ & 10 & 50 & 60 & 84.5 \\
$23-25$ & 3 & 8 & 11 & 15.5 \\
Total & 13 & 58 & 17 & 100
\end{tabular}

Sumber: Data primer diolah, 2021
Berdasarkan tabel Usia Responden tergambar bahwa remaja usia 19 tahun 22 tahun berjumlah 60 orang $(84.5 \%)$ dan responden usia 23 tahun - 25 tahun berjumlah 11 orang $(15.5 \%)$.

Tabel 4.3. Kadar Asam Urat Mahasiswa Diploma III Keperawatan Sekolah Tinggi Ilmu Kesehatan Dirgahayu Samarinda tahun Akademik 2020/2021

\begin{tabular}{|c|c|c|c|c|c|}
\hline $\begin{array}{l}\text { Respon } \\
\text { den }\end{array}$ & $\begin{array}{l}\text { Rentang } \\
\text { normal } \\
\text { urat } \\
\text { Laki- } \\
\text { laki } \\
3,4- \\
7,0 \\
\mathrm{mg} / \mathrm{dl}\end{array}$ & $\begin{array}{l}\text { asam } \\
\text { Pere } \\
\text { mpua } \\
\mathrm{n} \\
2,4- \\
5,7 \\
\mathrm{mg} / \mathrm{dl}\end{array}$ & $\begin{array}{l}\text { Diata } \\
\text { s } \\
\text { renta } \\
\text { ng } \\
\text { norm } \\
\text { al }\end{array}$ & $\mathrm{F}$ & $\%$ \\
\hline $\begin{array}{l}\text { Laki- } \\
\text { laki }\end{array}$ & 12 & 0 & 1 & 13 & 28.2 \\
\hline $\begin{array}{l}\text { Peremp } \\
\text { uan }\end{array}$ & 0 & 45 & 13 & 58 & 40.8 \\
\hline Jumlah & \multirow{2}{*}{\multicolumn{2}{|c|}{$\frac{57}{\text { Total }}$}} & 14 & 0 & 31 \\
\hline \multicolumn{2}{|r|}{10} & & & 71 & 100 \\
\hline
\end{tabular}

Sumber: Data primer diolah, 2021

Berdasarkan Tabel 4.3 Analisa data Kadar Asam Urat responden yang mengalami peningkatan Kadar Asam Urat di atas rentang normal berjumlah 14 responden $(31.0 \%)$ dan responden berada pada rentang normal berjumlah 57 orang mahasiswa $(68.9 \%)$.yaitu dari 71 orang total responden

\section{PEMBAHASAN}

Subyek dalam penelitian ini merupakan mahasiswa Program Studi Diploma III Keperawatan Sekolah Tinggi Ilmu Keshetan Dirgahayu Samarinda Tahun Akademik 2020/2021 remaja dengan rentang usia 18-25 tahun. Penelitian ini memilih subyek mahasiswa usia tersebut karena remaja pada usia tersebut juga mempunyairisiko terkena penyakit gout.

Berdasarkan hasil perhitungan tabel distribusi frekuensi data primer 
diolah dengan menggunakan persentase (\%). Untuk melihat Gambaran Kadar Asam Urat Pada Mahasiswa Diploma III Keperawatan Sekolah Tinggi Ilmu Kesehatan Dirgahayu Samarinda Tahun Akademik 2020/2021.Maka ditemukan Gambaran Asam urat Pada mahasiswa Diploma III Keperawatan tahun 2020 mengalami peningkatan kadar asam urat di atas rentang normal sebanyak 14 mahasiswa(31.0 \%) dari seluruh responden(71 mahasiswa), yang digambarkan dalam tabel 4.3.

Asam Urat merupakan hasil metabolism normal dari pencernaan protein berasal dari daging, hati, ginjal atau dari penguraian senyawa purin yang seharusnya dibuang melalui ginjal dalam urin serta melalui sitem pencernaan berupa feses atau melalui kulit berupa keringat (Sustrani, 2014)

Sumber purin ada dua yaitu: 1) Purin yang diproduksi sendiri oleh tubuh, dan 2) Purin yang didapatkkan dari asupan makanan berupa dari hasil tanaman maupun berasal dari hewan. Asam urat memiliki fungsi sebagai antioksidan dan regenesari sel. Metabolisme tubuh secara alamiah menghasilkan asam urat. Asam menjadi masalah bagi tubuh ketika kadar melewati batas normal (Noviyanti, 2015)

Menurut WHO (2016) kadar asam urat normal pada remaja pria berkisar sekitar 2-7,5 $\mathrm{mg} / \mathrm{dL}$, sedangkan pada remaja wanita dewasa adalah 2-6,5 $\mathrm{mg} / \mathrm{dL}$ pria dengan usia 40 tahun kadar normal asam urat yaitu $2-8,5 \mathrm{mg} / \mathrm{dL}$ dan pada wanita yaitu 2-8 mg/dL. Anak-anak usia 10-18 tahun, pada pria kadar normal asam urat adalah 3,6-5,5 $\mathrm{mg} / \mathrm{dL}$ dan pada wanita yaitu $3,6-4 \mathrm{mg} / \mathrm{dL}$. Insiden gout di Indonesia menempati urutan kedua setelah osteoartritis (Dalimartha, 2008 dikutip dari penelitian Festy dkk). Prevalensi gout di Indonesia diperkirakan 1,6- 13,6/100.000 orang, prevalensi ini meningkat seiring dengan meningkatnya umur (Tjokroprawiro,
2007). Prevalensi gout di Jawa Timur sebesar 17\%, prevalensi gout di Surabaya sebesar 56,8\% (Festy,2010).

Menurut (Sapti 2019), berikut ini komplikasi yang terjadiakibat tingginya kadar asam urat. 1).Kerusakan sendi Arthritis gout merupakan penyakit yang cukup ditakuti sebagian orang karena menimbulkan kerusakan sendi dan perubahan bentuk tubuh.Kerusakan sendi yang disebabkan tingginya asam urat dapat terjadi di tangan maupun kaki. Kerusakan tersebut terjadi karena asam urat menumpuk di dalam sendi dan menjadi kristal yang menganggu sendi.Sendi yang tertutup kristal asam urat menyebabkan jari-jari tangan maupun kaki menjadi kaku dan bengkok tidak beraturan. Namun yang ditakuti penderita bukan bengkoknya melainkan rasa sakit yang berkepanjangan. 2) Terbentuk tofi. Tofi adalah timbunan kristal monosodium urat monohidrat (MSUM) di sekitar persendian yang sering mengalami serangan akut atau timbul di sekitar tulang rawan sendi, synovial, bursa, atau tendon. Di luar sendi, tofi juga bisa ditemukan di jaringan lunak, otot jantung (miokard), katup bicuspid jantung (katup mitral), retina mata, dan pangkal tenggorokan (laring). Tofi tampak seperti benjolan kecil (nodul) berwarna pucat, sering teraba pada daun telinga, bagian punggung (ekstensor) lengan sekitar siku, ibu jari kaki, bursa di sekitar tempurung lutut (prepatela) dan pada tendon achiles. Tofi baru ditemukan pada kadar asam urat 10-11 mg/dL. Pada kadar $>11 \mathrm{mg} / \mathrm{dL}$, pembentukan tofi menjadi sangat progresif. Bila hiperurisemia tidak terkontrol, tofi bisa membesar dan menyebabkan kerusakan sendi sehingga fungsi sendi terganggu.Tofi juga bisa menjadi kerusakan sendi sehingga fungsi sendi terganggu.Tofi juga bisa menjadi koreng (ulserasi) dan mengeluarkan cairan kental seperti kapur yang mengandung 
MSU.Dengan adanya tofi, kemungkinan sudah terjadi pengendapan $\mathrm{Na}$ urat di ginjal.3) Penyakit jantung, Kadar asam urat yang tinggi dapat menimbulkan gangguan jantung. Bila penumpukan asam urat terjadi di pembuluh darah arteri maka akan mengganggu kerja jantung. Penumpukan asam urat yang terlalu lama dapat menyebabkan LVH (Left Ventrikel Hypertropy) yaitu pembengkakan ventrikel kiri pada jantung. 4) Batu Ginjal, Tingginya kadar asam urat yang terkandung dalam darah dapat menimbulkan batu ginjal. Batu ginjal terbentuk dari beberapa zat yang disaring dalam ginjal. Bila zat tersebut mengendap pada ginjal dan tidak bisa keluar bersama urine maka membentuk batu ginjal. Batu ginjal yang terbentuk diberi nama sesuai dengan bahan pembuat batu tersebut. Batu ginjal yang terbentuk dari asam urat disebut batu asam urat. 5). Gagal ginjal (nefropati gout),Komplikasi yang sering terjadi karena arthritis gout adalah gagal ginjal atau nefropati gout. Tingginya kadar asam urat berpotensi merusak fungsi ginjal. Adanya kerusakan fungsi ginjal dapat menyebabkan ginjal tidak bisa menjalankan fungsinya dengan baik atau mengalami gagal ginjal. Bila gagal ginjal terjadi ginjal tidak dapat membersihkan darah. Darah yang tidak dibersihkan mengandung berbagai macam racun yang menyebabkan pusing, muntah, dan rasa nyeri sekujur tubuh.

Menurut hasil laboratorium tes darah di gunakan untuk diagnosis hiperurisemia, sedangkan pemeriksaan urin untuk melihat ekskresi asam urat dan mendeteksi batu ginjal. Kadar normal asam urat dalam darah adalah 2 sampai $6 \mathrm{mg} / \mathrm{dL}$ untuk wanita dan 3 sampai $7,2 \mathrm{mg} / \mathrm{dL}$ untuk pria. Bagi yang berusia lanjut kadar tersebut lebih tinggi. Rata-rata kadar normal asam urat adalah 3.0 sampai $7,0 \mathrm{mg} / \mathrm{dl}$. Bila kadar asam urat darah lebih dari $7,0 \mathrm{mg} / \mathrm{dl}$ dapat menyebabkan serangan gout.Kadar asam urat yang tinggi di dalam darah melebihi batas normal menyebabkan penumpukan asam urat di dalam persendian dan organ tubuh lainnya. Penumpukan asam urat inilah yang membuat sendi sakit, nyeri, dan meradang.(Haryani and Misniarti, 2020) Bila hiperurisemia lebih dari 12 $\mathrm{mg} / \mathrm{dl}$ dapat menyebabkan terjadinya batu ginjal. Sebelum pemeriksaan di anjurkan puasa selama kurang lebih 4 jam sebelumnya. Juga tidak boleh menggunakan obat obatan tertentu yang dapat mempengaruhi hasil, yaitu: diuretika, etambutol, vinkristin, pirazinamid, tiazid, analgetik, vitamin $\mathrm{C}$ dan levodopan, begitupun makanan tertentu yang kaya purin (Iskandar, 2012).

Kadar asam urat normal pada pria dewasa 3,4-7,0 $\mathrm{mg} / \mathrm{dL}$ dan pada wanita dewasa 2,4-5-7 mg/dL. Asam urat yang beredar dalam darah tidak akan menimbulkan penyakit jika kadarnya berada pada batas normal. (Herliana, 2013)

\section{KESIMPULAN DAN SARAN}

Berdasarkan hasil perhitungan dan pembahasan dapat diambil kesimpulan, bahwa variabel yang diteliti sebagai Gambaran Kadar Asam Urat pada mahasiswa Program Studi Dipolma III Keperawatan Sekolah Tinggi Ilmu Kesehatan Dirgahayu Samarinda tahun Akademik 2020/2021 yaitu sebagai berikut :

1) Jenis kelamin responden, dilakukan Analisis frekuensi dalam persentase, Berdasarkan tabel Jenis Kelamin Responden tergambar bahwa laki laki berjumlah 13 orang (18.9\%) dan responden perempuan berjumlah 58 orang $(81.1 \%)$.

2) Usia responden Analisis frekuensi dalam persentase (\%) usia, seluruh responden termasuk dalam klasifikasi masa remaja akhir yaitu usia 18 - 25 tahun. Responden merupakan mahasiswa Program 
Studi Diploma III Keperawatan Sekolah Tinggi Ilmu Kesehatan Dirgahayu Samarinda tahun akademik 2020/2021, sesuai dengan program pendidikan pemerintah maka seseorang yang menempuh pendidikan perguruan tinggi dimulai dari usia 18 tahun.

3) Hasil pemeriksaan Kadar Asam Urat tergambar jelas dalam Analisis frekuensi dalam persentase (\%) bahwa Asam Urat Responden di atas Rentang Normal sebanyak 14 orang (31.0\%) dan Asam Urat dalam Rentang Batas Normal adalah 57 orang (68.9\%).Dari seluruh responden berjumlah 71 responden.

4) Untuk selanjutnya penelitian ini dilanjutkan dengan Analisis Faktorfaktor yang berhubungan dengan peningkatan kadar asam urat pada mahasiswa program Studi Diploma III Keperawatan Sekolah Tinggi Ilmu Kesehatan Dirgahayu Samarinda tahun Akademik 2021/2020.

\section{DAFTAR PUSTAKA}

Almatsier S., 2010, Penuntun Diet, Gramedia Pustaka, Jakarta

Alvin Budiono,dkk.(2016). Hubungan kadar asam urat dengan status gizi pada remaja di Kecamatan Bolangitang Barat Kabupaten Bolaang Mongondow. Bagian KimiaFakultas Kedokteran Universitas Sam Ratulangi Manado.e-Biomedik (eBm), Volume 4, Nomor 2, Juli-Desember 2016. Manado. Jurnal.

Carter, MA 2006, Gout dalam Patofosiologi: Konsep Klinis Proses-proses Penyakit, EGC, Jakarta pp. 1402-1405

Darmawan S,dkk (2016) Gambaran kadar asam urat darah pada pekerja kantor. Fakultas Kedokteran Bagian Biokimia Fakultas Kedokteran Universitas Sam Ratulangi Manado.e-Biomedik (eBm),Volume 4, Nomor 2, Juli-Desember 2016. Jurnal

Dianati,NA, (2015). Gout andhyperuricemia. Lampung: Jurnal MAJORITI. Vol.4, No. 3.

Depkes RI, 2018. (2018). Riset Kesehatan Dasar Nasional. Kementerian Kesehatan RI, 126.

Ema Madyaningrum, S.Kep., Ns., M.Kes., Ph.D. et al. (2020). Buku Saku Kader Pengontrolan Asam Urat Di Masyarakat.Yogyakarta:

HDSS Sleman bekerja sama dengan Tim Pengabdian MasyarakatFakultas

Kedokteran, Kesehatan Masyarakat dan Keperawatan Universitas Gadjah Mada.

Festy, P, dkk. (2010). Hubungan Antara Pola Makan Dengan Kadar Asam Urat Darah pada wanita Postmenopause di Posyandu Lansia Wilayah Kerja Puskesmas Dr. Soetomo Surabaya.Surabaya, universitas Muhammadiyah Surabaya. Jurnal

Hartaji, Damar A. (2012). Motivasi Berprestasi Pada Mahasiswa yang Berkuliah Dengan Jurusan Pilihan Orangtua.Skripsi strata satu, Fakultas Psikologi Universitas Gunadarma.

Haryani, S., \& Misniarti.(2020). Efektifitas Akupresur dalam Menurunkan Skala Nyeri 
Pasien Hipertensi Diwilayah Kerja Puskesmas Perumnas. Jurnal Keperawatan Raflesia, 2(1), 21-30. https://doi.org/10.33088/jkr.v2 $\underline{\mathrm{i} 1.491}$

Herliana, Ersi. (2013) Penyakit Asam Urat Kandas Berkat Herbal.Jakarta. Media

Junaidi Iskandar (2012) Rematik dan asam Urat.Edisi Revisi. PT: Buana Ilmu Populer. Jakarta.

Jordan et al. (2007) Rheumatology Guideline for the Management of Gout, The British Society for Rheumatology

Kemenkes RI.(2013). Riset Kesehatan Dasar Tahun 2012. Jakarta: Kementrian Kesehatan RI.

Khanna et al. (2012) Guidelines for Management of Gout.Part 2:Therapy and Antiinflammatory Prophylaxis ofAcute Gouty Arthritis. Fakultas American College of Rheumatol-ogy,.Vol. 64, No. 10, pp. 1447-1461

Krisnatuti.(2007). Perencanaan Menu untuk Penderita Gangguan Asam Urat. Jakarta: Penebarswadaya

Kamus Besar Bahasa Indonesia (KBBI) .Arti kata.online. kbbi.kemdikbud.go.id .

Kusumayanti ,D.(2014). Diet Mencegah Dan Mengatasi Gangguan Aasm Urat. Jurnal Ilmu Gizi Volume 5 Nomor 1, Februari 2014: 68-69, 71, Jurnal.

Lina N, Setiyono A,.(2014). Analisis Kebiasaan Makan yang Menyebabkan Peningkatan Kadar Asam Urat.Jurnal
Kesehatan Komunitas Indonesia.10:1004-1006. Jurnal.

Lingga, L. (2012). Bebas Penyakit Asam Urat Tanpa Obat. Jakarta Selatan: PT Agro Media Pustakan.

Neogi, T (2011), Clinical Practice of Gout, The New EnglandJournal of Medicine, pp. 443-447 Noviyanti.(2015). Hidup Sehat Tanpa Asam Urat. Yogyakarta. Notebook hal 21-72

Nurhayati.(2018). Hubungan Pola Makan Dengan Terjadinya Penyakit Gout (Asam Urat) Di Desa Limran Kelurahan Pantoloan Boya Kecamatan Taweli.Jurnal KESMAS, Vol. 7 No. 6, 2018.

Nursalam (2014).Proses dan Dokumentasi Keperawatan Konsep dan Praktik. Jakarta: Salemba Medika

Putra, \& Sitiatava,R.(2012). Panduan Riset Keperawatan dan Penulisan Ilmiah.Jogjakarta : D-Medika.

Setyowati, Syamsiatun N, Herawati. (2014). Obesitas, Pola Konsumsi Sumber Purin dan Lemak sebagai Faktor Risiko Terjadinya Asam Urat (Gout) pad Pasien Rawat Jalan di Pusakesmas Gamping II Sleman Yogyakarta. Jurnal Nutrisi.

Sipayung E, Warouw S, Manoppo J (2014). Hubungan Obesitas Dengan Peningkatan Asam Urat Pada Remaja di Sekolah Menengah Pertama.Jurnal 
Ilmu Kesehatan Anak Fakultas

Kedokteran Universitas Sam

Ratulangi Manado. Jurnal

Sutanto, Teguh. (2013) Deteksi

Pencegahan, Pengobatan

asam urat. Yogyakarta:Buku

Pintar

Sustrani, Alam \& Hadibroto.(2015).

Hipertensi.Jakarta:

PT

Gramedia Pustaka 